\title{
Peningkatan Kesadaran Berzakat, Infaq dan Bersedakah Bagi Masyarakat Melalui KKN Tematik Desa Membangun
}

\author{
Niswatin ${ }^{1}$, Heldy Vanni Alam ${ }^{2}$ \\ ${ }^{1}$ Jurusan Akuntansi, Fakultas Ekonomi, Universitas Negeri Gorontalo, J1. Jend. Sudirman No. 6 \\ Kota Gorontalo, Gorontalo 96128, Indonesia \\ ${ }^{2}$ Jurusan Manajemen, Fakultas Ekonomi, Universitas Negeri Gorontalo, Jl. Jend. Sudirman No. 6 \\ Kota Gorontalo, Gorontalo 96128, Indonesia \\ E-mail: niswatin@ung.ac.id ${ }^{1}$, heldyalam76@yahoo.com²
}

\begin{tabular}{ll}
\hline Article History: & Abstract: \\
Received: 03-11-2021 & Pengabdian ini bertujuan untuk meningkatkan pengetahuan \\
Revised: 08-11-2021 & masyarakat khususnya pada kelompok Usaha Kecil \\
Accepted: 09-11-2021 & Menengah tentang zakat. Pelaksanaan kegiatannya meliputi \\
& sosialisasi, pengumpulan dan pendistribusian tentang zakat. \\
& Program KKN pengabdian ini menawarkan program \\
& peningkatan pemahaman dan kesadaran masyarakat tentang \\
& zakat melalui Badan Amil Zakat Nasional (BAZNAS) yang \\
& berada Kab. Boalemo. Tahapan kegiatan yang dilakukan \\
& adalah melakukan sosialisasi tentang zakat pada Usaha \\
& Kecil Menengah yang berada di Desa Limbato dan Desa \\
& Piloliyanga. Selanjutnya melakukan pendistribusian zakat \\
& melalui program-program pendistribusian/penyaluran yang \\
& berada di Baznas. Hasil pelaksanaan kegiatan KKNT \\
Kengabdian ini diharapkan dapat meningkatkan kesadaran \\
Badan Amil Zakat, Zakat & masyarakat dalam membayar zakat. Mengingat pada \\
Maal, Usaha Kecil Menengah & umumnya masyarakat memanfaatkan zakat dalam \\
& peningkatkan potensi ekonomi.
\end{tabular}

\section{Pendahuluan}

Islam dalam konteks sejarah telah menempuh perjuangan panjang yang sudah tidak bisa dilepaskan dari sebuah perekonomian yang baik dan bermanfaat, sebagaimana yang lazim yang dijalankan oleh Rasulullah SAW. Al-qur'an menyatakan bahwa kesediaan berzakat dipandang sebagai indikator pertama dan utama seseorang yang akan mendapatkan kebahagiaan hidup dan rahmat Allah SWT.

"Ambilah zakat dari sebagian harta mereka, dengan zakat itu kamu membersikapan dan mensucikan mereka dan mendoalah untuk mereka. Sesungguhnya doa kamu itu (menjadi) ketentraman jiwa bagi mereka. Dan Allah maha mendengar lagi maha mengetahui" (Q.S AtTaubah:5)

Zakat memiliki kata dasar "zaka" yang berarti berkah, tumbuh, suci berkah dan baik. Secara terminologi zakat berarti aktivitas membayarkan harta tertentu untuk diserahkan kepada orang yang berhak menerima. Zakat ialah rukun Islam ketiga, yaitu harta yang wajib dibayarkan oleh setiap muslim yang memenuhi syarat (muzaki) untuk menyucikan hartanya dengan cara menyalurkan zakatnya kepada penerima zakat (mustahik). Zakat mengandung hikmah dan peran yang besar bagi peningkatan kesejahteraan hidup manusia dan penguatan solidaritas sosial secara menyeluruh. Dalam hal ini yang merekat solidaritas sosial melalui 
zakat adalah amil yang diangkat atau disahkan secara resmi oleh negara dan melaksanakan tugasnya secara amanah, profesional dan transparan.

Adapun pengertian zakat menurut ahli fikih adalah hak tertentu yang diwajibkan Allah SWT terhadap harta umat muslimin yang dikhususkan dan disebutkan dalam al-quraan Penentuan penerima zakat (mustahik) pada dasarnya telah ditetapkan dalam QS At Taubah ayat 60 terdapat delapan golongan mustahik yang berhak menerima: fakir, Miskin, Hamba sahaya, prang yang berhutang, Mualaf, Fisabilillah yaitu pejuang agama islam, Ibnu sabil yaitu orang yang kehabisan bekal dalam perjalanan jauh, Amil yaitu orang yang menyalurkan zakat.

Indonesia adalah negara dengan mayoritas penduduk muslim yaitu sekitar $87 \%$ dari total populasi dibandingkan dengan keyakinan lain yang diakui di Indonesia. Fakta ini menyiratkan bahwa zakat memiliki potensi besar dan dapat berkontribusi dalam mengurangi kemiskinan. Data zakat, di Indonesia menunjukkan bahwa terdapat kenaikan jumlah penghimpunan zakat, infak, dan sedekah dari tahun 2016 hingga 2017. Dalam rangka melaksanakan ketentuan Pasal 15 UU Nomor 23 Tahun 2011 tentang Pengelolaan Zakat, telah ditetapkan Keputusan Direktu Jendral Bimbingan Masyarakat Islam Nomor DJ.II/568 Tahun 2014 tentang Pembentukan Badan Amil Zakat Nasional Kabupaten/Kota SeIndonesia. Dalam hal ini, pembentukan BAZNAS Kabupaten Bantaeng yang menjadi lokasi penelitian. Kerjasama dan sinergi antara BAZNAS dan BAZNAS kabupaten/kota beserta lembaga zakat lainnya akan melahirkan penguatan gerakan zakat di seluruh wilayah negara Republik Indonesia.

Kabupaten Boalemo memiliki populasi penduduk muslim di tahun 2021 sekitar 143.760 Jiwa berdasarkan data BPS kabupaten Boalemo. Angka ini menunjukan zakat memiliki potensi besar dan berkontribusi mengurangi kemiskinan. Hal tersebut dapat terwujud dengan adanya pengelolaan zakat yang baik. Pada tahun 2016.

Permasalahan zakat yang terbesar adalah kurangnya kesadaran umat Islam untuk berzakat (maal). Fenomena ini tidak hanya terjadi pada akhir-akhir ini tetapi sudah sejak dahulu kala. Salah satu pelanggaran berat yang dilakukan oleh Qarun, umat nabi Musa AS., adalah tidak mau membayar zakat. Ketika Rasulullah SAW wafat, di antara pelanggaran yang dilakukan sebagian umat Islam adalah enggan membayar zakat. Jadi, keengganan membayar zakat bukanlah hal baru.

Berdasarkan uraian diatas, penulis tertarik untuk melaksanakan pengabdian tentang pengelolaan zakat dan bertujuan menuangkannya dalam tulisan ini dengan judul "Peningkatan Kesadaran Berzakat, Infaq dan Bersedakah Bagi Masyarakat Melalui KKN Tematik Desa Membangun.

\section{Metode}

Jenis dan pendekatan pengabdian ini menggunakan jenis penelitian lapangan. Penelitian lapangan pendekatan kualitatif (qualitative reseach) adalah suatu penelitian yang ditunjukan untuk mendeskripsikan dan menganalisis fenomena, peristiwa, aktivitas social, sikap, kepercayaan, persepsi pemikiran orang secara individual maupun kelompok.

Sumber data sekunder dalam penelitian ini adalah informasi-informasi yang dikumpulkan dari sumber yang telah ada antara lain peraturan-peraturan, surat keputusan, hasil penerimaan zakat dan lain-lain terkait dengan zakat penghasilan, dan dokumen-dokumen pendukung. Teknik pengumpulan data wawancara yang dilakukan adalah secara tatap muka 
dalam bentuk pelatihan kepada para pelaku Usaha Kecil Menengah (UKM) di Desa Limbato dan Piloliyanga. Informan yang dipilih merupakan informan yang mengetahui mengenai permasalahan yang diangkat sehingga informasi yang didapatkan akurat, relevan, dan sesuai dengan keadaan yang sebenarnya terjadi.

\section{Hasil}

\section{Kegiatan Survei}

Dalam pelaksanaan KKN Tematik Universitas Negeri Gorontalo, tahap awal tim melakukan survei lokasiyang akan menjadi tempat pelaksanaan. Hal pertama yang dilakukan adalah melakukan wawancara atau diskusi dengan kepala kantor Baznas, staf kemenang bagian zakat, kepala desa, sekertaris desa, dan ketua BUMDes. Wawancara dilakukan untuk menemukan informasi mengenai pemahaman zakat mal terhadap UKM di Kecamatan Tilamuta Kab Boalemo.

Hasil Survei menunjukan bahwa pelaku UKM di Desa Limbato dan Piloliyanga ratarata kurang mendapatkan edukasi tentang kesadaran membayar zakat pada para pelaku usaha atas zakat perdagangan mereka sehingga kurangnya kesadaran masyarakat untuk mengeluarkan zakat mal bagi para pelaku usaha. Namun sayangnya, masyarakat di Desa Limbato dan Piloliyanga belum tersentuh oleh penyuluhan tentang edukasi perhitungan zakat mal UKM.

Dari hasil survei didapatkan permasalahan yang tengah dihadapi oleh masyarakat bahwa masyarakat kurang memahami perhitungan zakat mal bagi UKM dan cara mengeluarkan zakat sehingga membuat masyarakat acuh tak acuh dengan zakat mal padahal mayoritas masyarakat di Desa Limbato dan Piloliyanga beragama Islam. Penelitian yang dilakukan pada UKM yang di laksanakan di kantor Kementrian Agama Kabupaten Boalemo yang dihadiri oleh 30 peserta yang terdiri dari para pelaku UKM di Desa Limbato dan Piloliyanga.
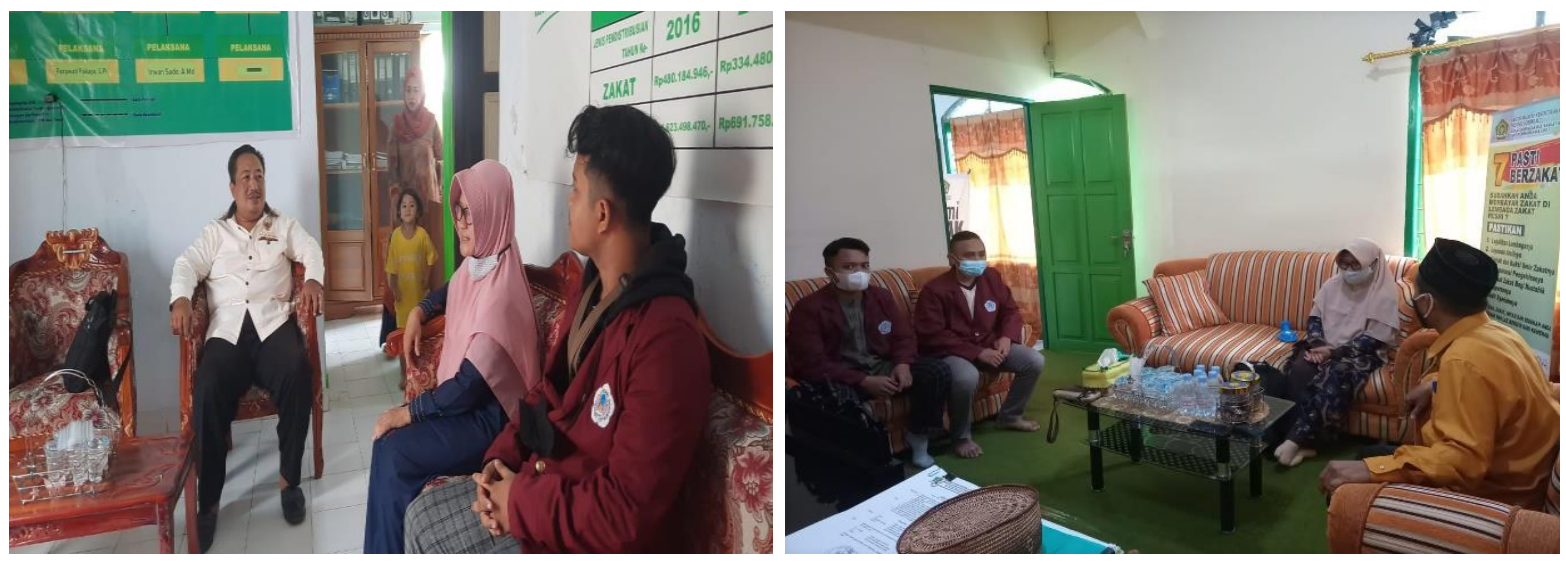

Gambar 1. Kunjungan Ke Baznas Boalemo dan Kementrian Agama Boalemo

\section{Kegiatan Sosialisasi}

Dalam kegitan sosialisasi ini, tim pelaksana beserta mahasiswa KKN Tematik memaparkan kegiatan yang akan diselenggarakan selama lima puluh hari. Manfaat yang 
diharapkan dari kegiatan sosialisasi adalah:

a. Terjalinnya kebersamaan antara dosen, mahasiswa, Pegawai Baznas, Pegawai Kementrian Agama, aparat desa, dan masyarakat.

b. Mendapatkan respon/dukungan yang baik sehingga kegiatan pengabdian selanjutnya dapat berjalan dengan baik

c. Terwujudnya kerjasama yang baik antara tim pelaksana, dosen, mahasiswa, Pegawai Baznas, Pegawai Kementrian Agama, aparat desa, dan masyarakat.

Sosialisasi dilakukan di Aula Kementrian Agama Kab Boalemo yang dihadiri oleh pegawai Kemntrian agama, pegawai Baznas, dosen, pemerintah desa, dan perwakilan masyarakat yakni ibu-ibu pelaku UKM didesa Limbato dan Piloliyanga. Peneliti hanya mengambil sedikit sampel karena masih dalam masa pandemi Covid-19 yang mengharuskan menjaga jarak dan mengurangi kerumunan. Kegiatan pengabdian KKN Tematik ini dilakukan dengan metode ceramah dan diskusi. Pelaksanaan sosialisasi lebih memfokuskan pada penjelasan program Baznas Mnegenai perhitungan zakat mal terhadap UKM. karena harta sesungguhnya adalah milik Allah yang dititipkan pada manusia untuk dikelola, kemudian akan dimintai pertanggungjawaban untuk apa harta tersebut, darimana, dan bagaimana memperolehnya.

Hasil penelitian menunjukan bahwa dalam pertumbuhan usaha kecil menengah mustahik dari omzet sebelum mendapatkan bantuan modal usaha dan sesudah mendapatkan bantuan modal usaha dana ZIS yang disalurkan oleh BAZNAS Kab Boalemo. Mereka menyatakan bahwa dana ZIS yang disalurkan digunakan untuk tambahan modal usaha dan pengembangan usaha, dan yang lebih lagi adalah BAZNAS Kab Boalemo dalam melakukan pengembalian modal ZIS tidak menggunakan system riba/bunga, sehingga membantu para mustahik terhindar dari rentenir yang mencekik dan menjauhkan mustahik dari perbuatan haram dan dosa.

Dengan berkembangnya usaha kecil menengah dengan modal berasal dari zakat, infaq, dan sedekah akan menyerap tenaga kerja. Hal ini mengakibatkan angka pengangguran bisa dikurangi, berkurangnya angka pengangguran akan berdampak pada meningkatnya daya beli masyarakat akan diikuti oleh pertumbuhan produksi, pertumbuhan sector produksi, pertumbuhan sector produksi inilah yang akan menjadi salah satu indikator adanya pertumbuhan ekonomi. Zakat, infaq, dan sedekah dapat dijadikan sebagai salah satu bentuk modal usaha bagi usaha mikro.

Dengan demikian ZIS memiliki pengaruh yang sangat besar dalam berbagai hal kehidupan umat, diantaranya adalah pengaruh dalam bidang ekonomi. Pengaruh zakat, infaq dan sedekah lainnya adalah terjadinya pembagian pendapatan secara adil kepada masyarakat Islam.

Modal usaha yang diberikan diharapkan terus berputar. Tidak hanya habis dalam beberapa hari saja, namun dapat digunakan untuk membantu usaha mereka yang dapat memenuhi kebutuhan hidupnya dan juga keluarga. Adanya zakat, infaq, dan sedekah ini sangat berpotensi, karena dapat dimanfaatkan dan didayagunakan sebaik-baiknya oleh para mustahik. Sehingga terbentuk kehidupan masyarakat yang harmonis, dengan tatanan social yang berlandaskan pada nilai-nilai keadilan dan kemanusiaan yang bersifat universal. Dengan begitu maka perekonomian mustahik akan sedikit terbantu dengan adanya dana bantuan modal usaha dari BAZNAS Kab Boalemo. 
Pemahaman akuntansi zakat dan tingkat religiusitas terhadap kesadaran membayar zakat pada para pelaku usaha atas zakat perdagangan mereka. keputusan para muzakki untuk mau mengeluarkan zakatnya sangat menarik untuk ditelusuri, dimana dilihat dari sisi keimanan yang mendasari munculnya kesadaran untuk mengeluarkan zakat tersebut yaitu adanya pemahaman dari fikih zakat tersebut, selain itu pengamalan serta janji yang telah Allah jelaskan dalam Al Quran menjadi pegangan bahwa zakat merupakan harta yang wajib untuk dikeluarkan. Dilihat dari sisi akuntansi, juga berhubungan dengan perilaku akuntansi dan perhitungan serta keputusan untuk mengeluarkan zakat tersebut, konsep perhitungan yang benar diperlukan dalam hal menghitung zakat perdagangan ini, karena masih banyaknya pelaku usaha yang belum memahami dasar dari perhitungan zakat tersebut. Penelitian ini dilakukan dengan mengambil smpel sebanyak 25 responden, yaitu para pelaku UKM Muslim yang ada di desa Limbato dan Piloliyanga Kabupaten Tilamuta Kecamatan Boalemo.

Penelitian ini menggunaan media pelatihan sebagai alat pendataan. sehingga dapat menunjukkan hasil dari penelitian ini dimana terdapat peningkatan pemahaman para pelaku UKM tentang kesadaran pembayaran zakat Mal, tetapi ada pengaruh yang cukup besar dari tingkat religiusitas terhadap kesadaran para pelaku usaha untuk mau mengeluarkan zakat perdagangan mereka.
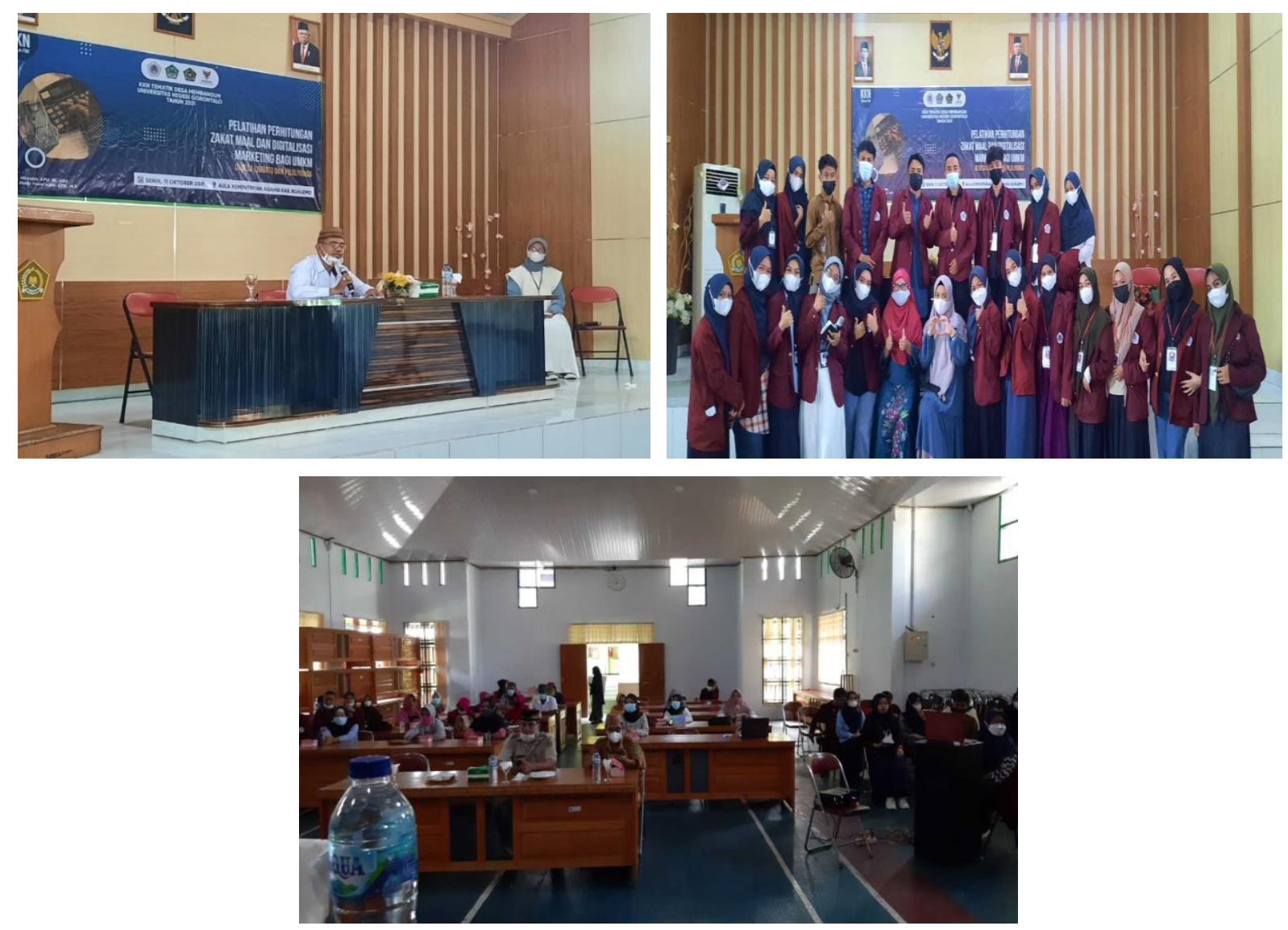

Gambar 2. Proses Pemberian Materi 


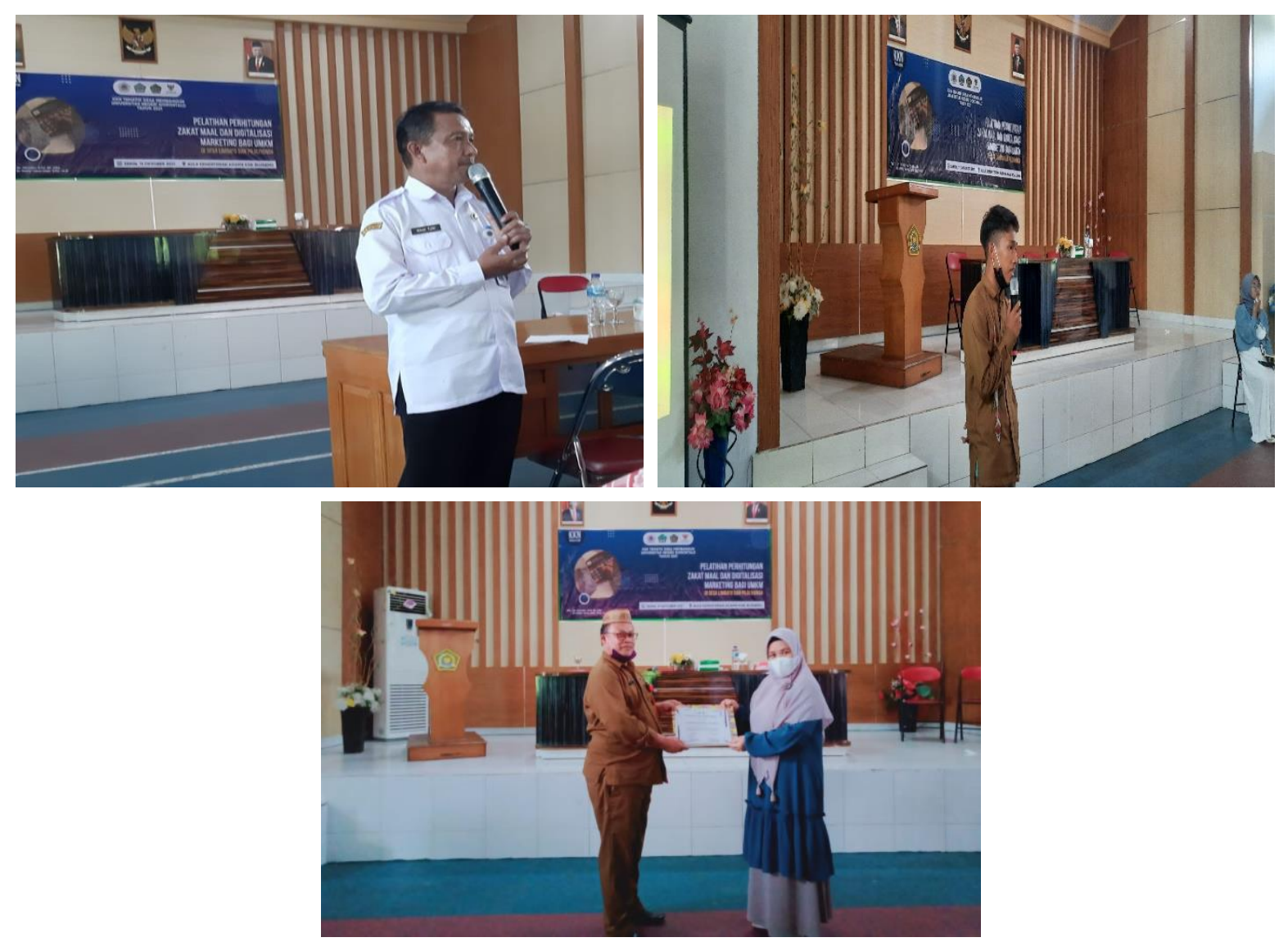

Gambar 3. Sosialisasi Pelatihan Perhitungan zakat mal dan digitalisasi Marketing

\section{Diskusi}

Menurut bahasa (Lunghat): tumbuh, berkembang, kesuburan atau bertambah (H.R AtTirmidzi) menurut hukum islam (istilah syara') zakat adalah nama bagi suatu pengambilan tertentu dari harta yang tertentu, menurut sifat-sifat yang tertentu, menurut sifat-sifat yang tertentu dan untuk diberikan kepada golongan tertentu (Al Mawardi dalam kitab Al Hawiy)

Zakat Maal (harta) menurut bahasa harta adalah segala sesuatu yang diinginkan sekali oleh manusia untuk memiliki memanfaatkan dan menyimpannya. Menurut syar'a harta adalah segala sesuatu yang dimiliki (dikuasai) dan dapat digunakan (dimanfaatkan) menurut ghalibanya (lazim).

Zakat terbagi menjadi dua jenis, yaitu zakat jiwa (zakah al-fithr) dan zakat harta (zakah al-mal). Zakat memiliki ketentuan-ketentuan operasional yang lengkap meliputi jenis harta yang terkena zakat, tarif zakat, batas minimal harta terkena zakat (nishab), batas waktu pelaksanaan zakat (haul) hingga sasaran pembelanjaan zakat. Zakat fitrah dapat dikeluarkan setiap muslim yang menemui sebagian atau keseluruhan bulan Ramadan dan bulan Syawwal, sedangkan zakat maal mencakup emas, perak, hasil perniagaan, pertanian, pertambangan, ternak dan harta temuan.

Semua dapat disebut dengan maal (harta) apabila memenuhi dua syarat, yaitu dapat dimiliki, disimpan, dihimpun, dikuasai, dan dapat diambil manfaatnya sesuai dengan ghalibnya. Sesuatu dapat disebut dengan maal (harta) apabila memenuhi 2 (dua) syarat, yaitu: 
a. Dapat dimiliki, disimpan, dihimpun, dikuasai

b. Dapat diambil manfaatnya sesuai dengan ghalibnya. Misalnya rumah, mobil, ternak, hasil pertanian, uang, emas, perak, dll.

PSAK 109 adalah pernyataan standar keuangan yang bertujuan untuk mengatur pengakuan, pengukuran, penyajian dan pengungkapan transaksi zakat dan infak/sedekah. Pernyataan ini tidak berlaku untuk entitas syariah yang menerima dan menyalurkan zakat dan infak/sedekah tetapi bukan sebagai kegiatan umumnya. Entitas syariah tersebut mengacu kepada PSAK 101: Penyajian Laporan Keuangan Syariah (Ikatan Akuntan Indonesia, 2019). Syarat-syarat Kekayaan yang Wajib Zakat:

1. Milik Penuh (Almilkuttam) yaitu: harta tersebut berada dalam kontrol dan kekuasaanya secara penuh, dan dapat diambil manfaatnya secara penuh. Harta tersebut didapatkan melalui proses pemilikan yang dibenarkan menurut syariat islam, seperti : usaha, warisan, pemberian negara atau orang lain dan cara-cara yang sah. Sedangkan apabila harta tersebut diperoleh dengan cara yang haram, maka zakat atas harta tersebut tidaklah wajib, sebab harta tersebut harus dibebaskan dari tugasnya dengan cara dikembalikan kepada yang berhak atau ahli warisnya.

2. Berkembang yaitu: harta tersebut dapat bertambah atau berkembang bila diusahakan atau mempunyai potensi untuk berkembang

3. Cukup Nishab Artinya harta tersebut telah mencapai jumlah tertentu sesuai dengan ketetapan syara'. sedangkan harta yang tidak sampai nishabnya terbebas dari Zakat

4. Lebih Dari Kebutuhan Pokok (Alhajatul Ashliyah) yaitu Kebutuhan pokok adalah kebutuhan minimal yang diperlukan seseorang dan keluarga yang menjadi tanggungannya, untuk kelangsungan hidupnya. Artinya apabila kebutuhan tersebut tidak terpenuhi yang bersangkutan tidak dapat hidup layak. Kebutuhan tersebut seperti kebutuhan primer atau kebutuhan hidup minimum (KHM), misal, belanja sehari-hari, pakaian, rumah, kesehatan, pendidikan, dsb.

5. Bebas Dari Hutang yaitu Orang yang mempunyai hutang sebesar atau mengurangi senishab yang harus dibayar pada waktu yang sama (dengan waktu mengeluarkan zakat), maka harta tersebut terbebas dari zakat.

6. Berlalu Satu Tahun (Al-Haul) Maksudnya adalah bahwa pemilikan harta tersebut sudah belalu satu tahun. Persyaratan ini hanya berlaku bagi ternak, harta simpanan dan perniagaan. Sedang hasil pertanian, buah-buahan dan rikaz (barang temuan) tidak ada syarat haul.

\section{Harta (maal) yang Wajib Zakat}

\section{a. Emas Dan Perak}

Emas dan perak merupakan logam mulia yang selain merupakan tambang elok, juga sering dijadikan perhiasan. Emas dan perak juga dijadikan mata uang yang berlaku dari waktu ke waktu. Islam memandang emas dan perak sebagai harta yang (potensial) berkembang. Oleh karena syara' mewajibkan zakat atas keduanya, baik berupa uang, leburan logam, bejana, souvenir, ukiran atau yang lain.

Termasuk dalam kategori emas dan perak, adalah mata uang yang berlaku pada waktu itu di masing-masing negara. Oleh karena segala bentuk penyimpanan uang seperti tabungan, deposito, cek, saham atau surat berharga lainnya, termasuk kedalam kategori emas dan perak. sehingga penentuan nishab dan besarnya zakat disetarakan dengan emas dan perak.

Demikian juga pada harta kekayaan lainnya, seperti rumah, villa, kendaraan, tanah, dll. 
Yang melebihi keperluan menurut syara' atau dibeli/dibangun dengan tujuan menyimpan uang dan sewaktu-waktu dapat di uangkan. Pada emas dan perak atau lainnya yang berbentuk perhiasan, asal tidak berlebihan, maka tidak diwajibkan zakat atas barang-barang tersebut.

b. Binatang Ternak

Hewan ternak meliputi hewan besar (unta, sapi, kerbau), hewan kecil (kambing, domba) dan unggas (ayam, itik, burung).

c. Hasil Pertanian

Hasil pertanian adalah hasil tumbuh-tumbuhan atau tanaman yang bernilai ekonomis seperti biji-bijian, umbi-umbian, sayur-mayur, buah-buahan, tanaman hias, rumput-rumputan, dedaunan, dll.

d. Harta Perniagaan

Harta perniagaan adalah semua yang diperuntukkan untuk diperjual-belikan dalam berbagai jenisnya, baik berupa barang seperti alat-alat, pakaian, makanan, perhiasan, dll. Perniagaan tersebut di usahakan secara perorangan atau perserikatan seperti CV, PT, Koperasi, dsb.

e. Ma-din dan Kekayaan Laut

Ma'din (hasil tambang) adalah benda-benda yang terdapat di dalam perut bumi dan memiliki nilai ekonomis seperti emas, perak, timah, tembaga, marmer, giok, minyak bumi, batu-bara, dll. Kekayaan laut adalah segala sesuatu yang dieksploitasi dari laut seperti mutiara, ambar, marjan, dll.

f. Rikaz

Rikaz adalah harta terpendam dari zaman dahulu atau biasa disebut dengan harta karun. Termasuk didalamnya harta yang ditemukan dan tidak ada yang mengaku sebagai pemiliknya.

Melalui kegiatan Pengabdian KKN Tematik ini, ada beberapa hal yang dijadikan target, yaitu peningkatan pengetahuan masyarakat 1) Sikap/kesadaran, setelah adanya Edukasi perhitungan zakat mal bagi UKM di desa Limbato dan Piloliyanga; 2) Pengetahuan, setelah adanya Edukasi perhitungan zakat mal bagi UKM di desa Limbato dan Piloliyanga dapat memahami bahwa seharusnya mereka sudah harus memporsikansebahagian harta mereka bagi zakat Mal.

\section{Kesimpulan}

Berdasarkan pembahasan yang telah dikemukakan di dalam bab-bab sebelumnya mengenai Pengelolaan Zakat, Infaq dan Sedekah Dalam Upaya Meningkatkan Pendapatan Ekonomi Pelaku UKM di BAZNAS kabupaten Boalemo maka dapat ditarik kesimpulan sebagai berikut:

1. Dana zakat, infaq dan sedekah yang dikumpulkan oleh Badan Amil Zakat Nasional (BAZNAS) Kabupaten Boalemo bersumber dari warga masyarakat Kabupaten Boalemo dan Dinas-Dinas Kabupaten Boalemo. Pengelolaan dana ZIS ini disalurkan kepada para pelaku usaha kecil menengah berupa barang atau uang untuk modal usahanya demi mengembangkan usaha mereka dan membantu meningkatkan ekonomi mereka. 
2. Upaya meningkatkan pendapatan ekonomi pelaku UKM melalui dan ZIS dari pengelolaan zakat, infaq, dan sedekah yang dilakukan oleh BAZNAS Kabupaten Boalemo dilihat dari perubahan tingkat ekonomi mustahik setelah mendapatkan dana bantuan modal usaha. Setelah mendapatkan bantuan modal usaha tersebut pendapatan atau perekonomian mustahik meningkat setiap bulannya, sehingga pengelolaan zakat, infaq dan sedekah yang dilakukan oleh BAZNAS Kabupaten Boalemo sudah sangat membantu dalam meringankan beban mustahik dan juga membebaskan mustahik dari jeritan rentenir.

\section{Pengakuan/Acknowledgements}

Terima kasih kepada seluruh pihak yang telah memberikan kontribusi baik secara langsung maupun tidak langsung sehingga kegiatan pengabdian ini dapat terlaksana dengan baik. Terima kasih kepada Pemerintah Desa Limbato, Desa Piloliyanga dan masyarakat desa Limbato dan Piloliyanga yang telah memberikan kesempatan bagi penulis untuk melaksanakan kegiatan pengabdian ini. Terima kasih kepada seluruh mahasiswa KKN Tematik Desa Membangun Periode II Tahun 2021 Wafiq Aziza Nursafitri, Muthia Maulita Anggraeni, Indrawati Idris, Tarizza Salsabila Nurlaila Busura, Rifki Putra, Rifal Dukalang, Nitra Chewy Ilahude, Asnun Aliwu Tomelo, Maya Wulandari Iskandar, Zufraya Yusuf, Febrianto Maraya, Muh.Fachrul Ilmi Djibu, Utari Apriliyani Dumbela, Nurul Atma Saleh, Muhamad Abd Latif, Zuhriayana K. Rivai, Ari Kurniawan Putra, Sri Wahyuningsi Abdulah, Alrid Zulfikar H. Ekksan, Mohammad Ifdal Husain, Adriansah Polutu, Moh. Ichsanul Sya'ban Mudassir, Moh Samsul, Hainun Putri Y. Ahmad, Nur Aista Adam, Yenny Maryina Junus, Arwin W. Antu, Astari Yunita, Merlin Lauhi, Apniati Kiraman, Cindriyanti Napulo, Annisa Meliyana, Hairunnisa Ismail, Aryo Syahputra. Semoga apa yang telah dilaksanakan dalam pengabdian ini dapat memberikan manfaat bagi masyarakat Desa Limbato dan Desa Piloliyanga.

\section{Daftar Referensi}

Widodo, Nova Maulud, Sundaru Guntur Wibowo, and Yana Dwi Christanti. 2020. "Perspektif Pernyataan Standar Akuntansi Keuangan Entitas Mikro Kecil Menengah Menurut Pandangan Hukum Dan Syariah (Studi Kasus pada UKM Desa Banjarejo Panekan Magetan)." Monex: Journal of Accounting Research-Politeknik Harapan Bersama Tegal $9.1: 62-69$.

Ginting, BR, \& Sri Wahyuni. 2020. Pengaruh Pemahaman Akuntansi Zakat Dan Tingkat Religiusitas Terhadap Kesadaran Membayar Zakat Pada Pelaku Usaha Kecil Dan Menengah (Ukm) Muslim Di Kota Medan.

Aini, Nur, and Abdillah Mundir. 2020. "Pengelolaan Zakat, Infaq dan Sedekah dalam Upaya Meningkatkan Pendapatan Ekonomi Pelaku UKM di BAZNAS Kabupaten Boalemo." MALIA: Jurnal Ekonomi Islam 12.1 : 95-108.

Rohman, Fatchur, Aan Zainul Anwar, and Subadriyah Subadriyah. 2017. "Analisa Potensi Zakat UKM Mebel Melalui BAZNAS untuk Peningkatan Kesejahteraan Masyarakat Jepara." Perisai: Islamic Banking and Finance Journal 1.3 : 200-214.

Tanjung, Dewi Sundari. 2019. "Pengaruh Zakat Produktif Baznas Kota Medan Terhadap 
Pertumbuhan Usaha Dan Kesejahteraan Mustahik Di Kecamatan Medan Timur." AtTawassuth: Jurnal Ekonomi Islam 4.2 : 349-370. 